International Journal of Agriculture, Environment and Bioresearch

Vol. 5, No. 01;2020

ISSN: 2456-8643

\title{
USE OF PRINCIPAL COMPONENT ANALYSIS (ACP) FOR THE PHYSICO- CHEMICAL CHARACTERISATION OF SOILS IN RICE FIELDS IN THE GHARB PLAINS
}

\author{
El amrani Btissam*, Rahmouni Thami, Belghyti Driss and El kharrim Khadija \\ Department of Biology, Laboratory Agro-physiology, Biotechnology, Environment and Quality, Kenitra Faculty of \\ Sciences / Ibn Tofail University. B.P .: 133/14000 Kenitra (Morocco)
}

https://doi.org/10.35410/IJAEB.2020.5474

\begin{abstract}
The physico-chemical parameters of the soil surface horizons of six rice fields in the Gharb plain (Morocco) show a variation between the beginning and the end of the vegetative cycle of the studied rice. The clos are characterized by a basic $\mathrm{pH}$ related to submersion, an appreciable content of organic matter and a variable sodicity associated with a strong cation exchange capacity and secondly the nature of ground of the rice fields .

In Morocco, rice growing locates in the area of Gharb and Larache (North-West of Morocco).

The location of these rice plantations is due to the presence of three factors: a warm climate and not very wet, proximity of the Sebou wadi where the pumping the water of irrigation is carried out, and the propitious nature of the ground.

The objective of our work is to evaluate the physicochimical quality of surface waters of five clos of the rice plantations of the area of Gharb in Morocco (town of Sidi Allal Tazi and Bil Ksiri).

The analysis focused to 9 physico-chemical parameters of ground such as soil parameters such as the hydrogen potential, limestone; texture, electric conductivity, $\mathrm{Na}+\mathrm{CEC}, \mathrm{MO}, \mathrm{P} 2 \mathrm{O} 2$ et $\mathrm{K} 2 \mathrm{O}$.
\end{abstract}

Keywords: rice plantations, physicochimical, irrigation, Morocco..

\section{INTRODUCTION}

The rice fields are Complex medium having both an aquatic and edaphic biotope, from where nutritive richness linked to a diversity of plant, animal and microbial, and agro-ecosystems that remain flooded almost permanently during cultural period (at the end of May to middle of October), and are dried out the rest of the year.

The soil is the key element of terrestrial ecosystems, in particular agro-systems including rice cultivation, it seems to condition much of this culture, which is of all agricultural activities the one that uses and abuses the most natural resources of the biosphere [15]. 
It is a living medium, whose quality can be irreversibly altered by maladjusted human interventions.

Rice can be grown on a wide variety of soils. Soils with good water capacity of retention are best, so clay soils with high organic matter content are ideal, but soils with high silt content are also appropriate. Sandy soils are not indicated for rice production.

The objective of the present study is the description of the physico-chemical parameters of the aquatic phase of the rice ecosystem, and the understanding of the fundamental characteristics. To solve this problem, we carried out a follow-up of the physical and chemical parameters ( $\mathrm{pH}$, electrical conductivity, Limestone, $\mathrm{Na}+, \mathrm{CEC}, \mathrm{MO}, \mathrm{P} 2 \mathrm{O} 2, \mathrm{~K} 2 \mathrm{O}$, clay, silt and sand) during of the companions 2015,2016 and 2017 . The data were subjected to a factorial correspondence analysis (ACP) in order to highlight of eventual changes suffered by soils in the rice fields.

\section{MATERIAL AND METHODS Study Zone}

The Gharb plain is located in the Atlantic littoral zone between latitudes $34^{\circ}$ and $34^{\circ} 45^{\prime} \mathrm{N}$. It constitutes the northern half of a well-defined hydrogeological unit called the Gharb-Maamora basin; the Maamora constitutes the southern half of the basin.

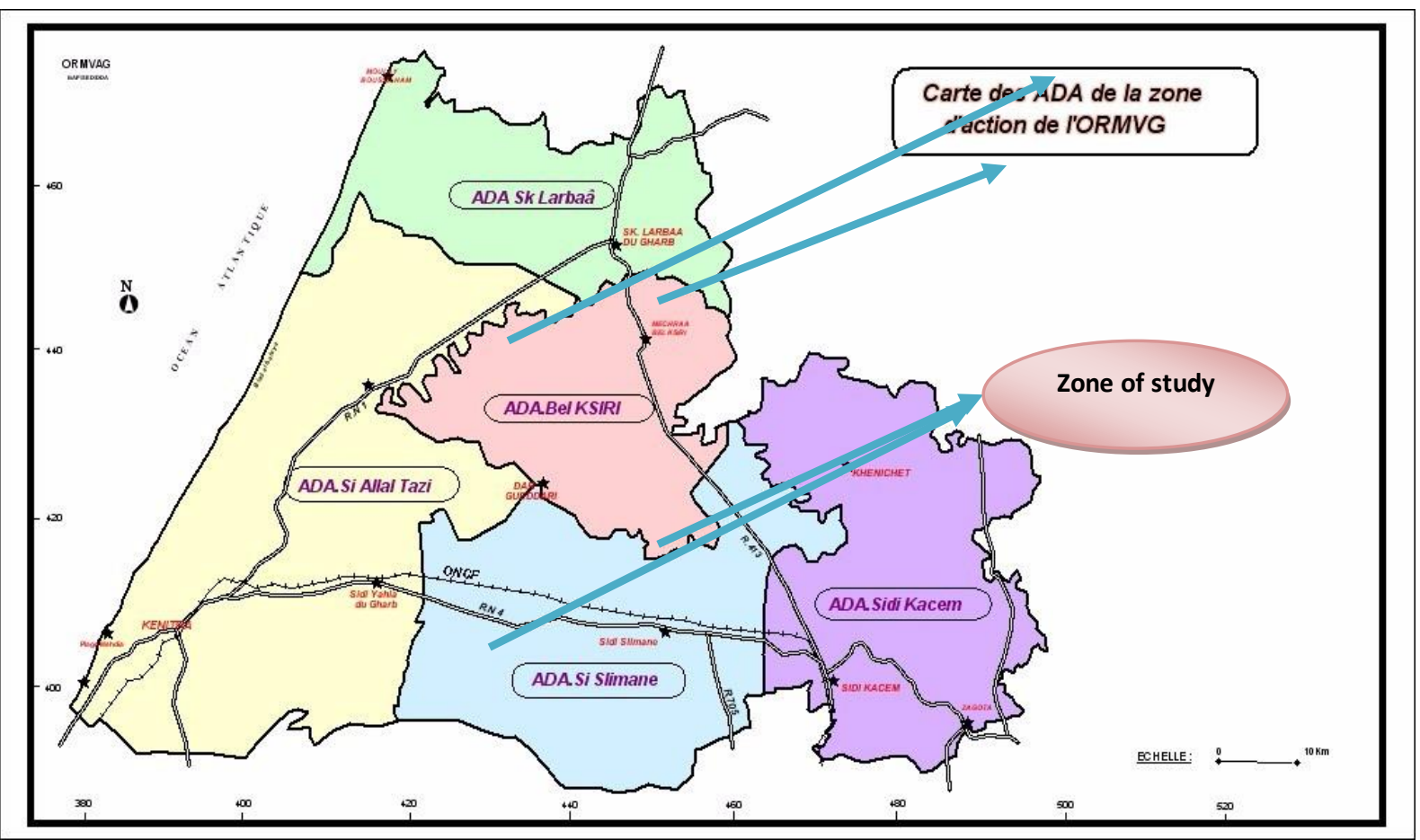

\section{Climatic context}

The climate of our zone of study is hot and moderated. The winter is characterized by precipitation more important than in summer. The annual average temperature recorded in this 
region is approximately $19.2^{\circ} \mathrm{C}$. The annual average precipitation are $570 \mathrm{~mm}$, in July is the driest month, with only $0 \mathrm{~mm}$. In December, the precipitation are the most important of the year with an average of $114 \mathrm{~mm} .26 .7{ }^{\circ} \mathrm{C}$ make of the hottest August of the year, January is the coldest month of the year and the average temperature in this period is $12.4{ }^{\circ} \mathrm{C}$.

\section{GEOLOGIC AND HYDROGEOLOGIC CONTEXT}

\section{Geologic Context}

The quaternary persistence of the collapse movement of the South Rifain furrow was at the origin of the creation of the vast plain of Gharb [12].

It corresponds to a vast alluvial triangle, marshy, born of the Sebou and the Beht, defended at the edge of the ocean by a rise of ancient dunes and which is between Rabat, Dar Bel Amri and Arbaoua. The Neogene rarely shows itself, despite being very thick, above the old basement collapsed more than 2000m deep [14].

The pre-rifal zone is represented by marginal formations of the external groove,

The upper Cretaceous is characterized by a marly predominance. The lias and the Dogger are limestone, the upper Jurassic is schisto-sandstone, the upper Cretaceous is marly and marllimestone [3].

\section{Hydrogeological context}

The area of the Gharb-Maamora hydrogeological basin is 7500 square kilometers; these limits are constituted by the ocean Atlantic the hills of Lalla Zohra in the North, those of Ksiri, BouDraa, Outita in the East and the reliefs between Khemisset and Tiflet in the South [3].

\section{The Soils}

The plain of Gharb is a the regions most studied regions from the pedological point of view in Morocco. The main types of soils encountered are:

The DEHS: of poorly evolved soils alluvial (Xerofluvents and Xerochrepts) formed on alluvial deposits of generally balanced texture along of alluvial (light DEHS) or fine while going away from the wadis (heavy DEHS). These soils are most often well drained and well structured. They are apt for all crops acclimated to the region. This type of soil represents about $22 \%$ of the total area of Gharb.

> The TIRS: Vertisols (pelloxererts) in the center of the plain. These soils represent a clay texture with a smectitic dominance (swelling clays). They have good chemical fertility but unfavorable physical properties both in the dry state (very hard) and in the wet state (plastics, tights and poor drainage). TIRS cover approximately $34 \%$ of the total area of the perimeter. 
The MERJAS: hydro-hydromorphic soils and aquantics (Xeropsamments) of merjas and poorly drained depressions. These are soils with variable textures. They occupy about $15 \%$ of the area of Gharb.

$>$ The R'MELs: Fersiallitic soils Mediterranean Red (Rodoxeralfs and Palexeralfs) having a sandy horizon on the surface and a deep clay horizon.

$>$ Other younger R'MEL soils are developed on the dunes of the Sahel. These present a texture a very sandy on all the profil. They are very filtering soils with low water retention capacity and mineral elements. They cover $12.5 \%$ of the perimeter.

$>$ Other soils: these are raw mineral soils, calcimagnetic and isohumic soils (Xerofluvents, Calcixerolls, and Xerochrepts).

\section{MATERIALS AND METHODS}

\section{Sampling}

The sampling adopted in this study consists in exploiting types of soils that characterize the studied area namely; the Vertisols, calcimagnetic soils, Fersiallitic soils, hydromorphs and isohumic soils. The samples were taken in the horizon $0-20 \mathrm{~cm}$ using an auger; they were dried in the open air and then crushed and sieved.

\section{Physico-chemical analyzes}

It has levy five clos who have been taken study area for three months. All these analyzes are carried out in the laboratory of ORMVAG Kenitra, by chemicals, appareils such as digital burettes, flame photometer, spectrophotometer, $\mathrm{pH}$ meter, Conductivity meter, and other materials.

These samples are recorded in the register of the ORMVAG laboratory and are the subject of a series of physicochemical analyzes.

These samples are recorded in the register of the ORMVAG laboratory and are the subject of a series of physicochemical analyzes. The quality parameters selected and analyzed are the physicochemical parameters: $\mathrm{pH}$, electrical conductivity (EC), cation exchange capacity (CEC), organic matter (OM), available phosphorus (P2O5) and exchangeable potassium (K2O).

$>$ The $\mathbf{p H}$ of a diluted suspension of $10 \mathrm{~g}$ of soil and $25 \mathrm{ml}$ of distilled water was measured using a glass electrode $\mathrm{pH}$ meter at room temperature with magnetic stirring.

$>$ The assimilable phosphorus (P2O5): is determined by the OLSEN method in which the extraction is made by sodium hydrogencarbonate at a $\mathrm{pH}$ of 8.5 , this method is based on the formation and reduction a complex ortho Phosphoric and molybdic acid (sky blue color). The reading of the phosphorus content is carried out using a Visible-model JENWAY 6405 UV spectrophotometer at a wavelength of 825 $\mathrm{nm}$. The result expressed in ppm [13]. 
$>$ The content the organic matter (OM) was evaluated according to the Walkley and Black method, which consists of a cold oxidation of the organic carbon fraction by potassium dichromate $(\mathrm{K} 2 \mathrm{Cr} 2 \mathrm{O} 7$ at $1 \mathrm{~N})$ in an acid medium and a titration in return by Mohr salt $(\mathrm{SO} 4 \mathrm{Fe}, \mathrm{SO} 4(\mathrm{NH} 4) 2.6 \mathrm{H} 2 \mathrm{O}$ at $0.5 \mathrm{~N})$. The rate of organic matter is estimated multiplying the percentage of organic carbon by the factor 1,724 [19]

$>$ Cation exchange capacity (CEC): determined by the sodium acetate method.

$>$ Electrical conductivity (EC) was evalued on soil suspensions with respective soilwater ratios of $2 / 5$ and $1 / 10$.

$>$ Total limestone was determined by gravimetry after attacking carbonates with hydrochloric acid:

$$
2 \mathrm{HCl}+\mathrm{CaCO} 3->\mathrm{CaCl} 2+\mathrm{CO} 2+\mathrm{H} 2 \mathrm{O}
$$

The content of the organic matter (OM) was evaluated according to the Walkley and Black method, which consists of a cold oxidation of the organic carbon fraction by potassium dichromate ( $\mathrm{K} 2 \mathrm{Cr} 2 \mathrm{O} 7$ at $1 \mathrm{~N}$ ) in an acid medium and a titration in return by Mohr salt (SO4Fe, $\mathrm{SO} 4(\mathrm{NH} 4) 2.6 \mathrm{H} 2 \mathrm{O}$ at $0.5 \mathrm{~N}$ ). The rate of organic matter is estimated by multiplying the percentage of organic carbon by the factor 1,724 [19].

\section{RESULTS}

The results of the physico-chemical analyzes of the Bel Ksiri and Allal Tazi rice soils have been recorded in Table 1 and Figures 1 and 2.

Table 1: statistical variability of the physico-chemical parameters.

\begin{tabular}{|l|l|l|l|l|l|l|l|l|l|l|l|}
\hline & PH & CE & MO & CEC & Na+ & Calcaire & P2O5 & K2O & Argile & Limon & sable \\
\hline $\begin{array}{l}\text { C1 } \\
(7 / 2015)\end{array}$ & 8,2 & 1,6 & 2,5 & 24 & 3,5 & 14,8 & 16 & 250 & 53 & 40 & 50 \\
\hline $\begin{array}{l}\text { C2 } \\
(7 / 2015)\end{array}$ & 7,8 & 1,2 & 2,8 & 28 & 1,5 & 15,6 & 31 & 470 & 54 & 41 & 30 \\
\hline $\begin{array}{l}\text { C3 } \\
(7 / 2015)\end{array}$ & 7,95 & 1,3 & 2 & 20 & 5 & 14 & 28 & 310 & 55 & 42 & 25 \\
\hline $\begin{array}{l}\text { C4 } \\
(7 / 2015)\end{array}$ & 8,05 & 3,2 & 2,7 & 30 & 1,3 & 16 & 19 & 310 & 56 & 39 & 25 \\
\hline $\begin{array}{l}\text { C5 } \\
(7 / 2015)\end{array}$ & 8,15 & 3,5 & 2,5 & 18 & 5,2 & 13,5 & 45 & 310 & 52 & 43 & 20 \\
\hline MOY & 8,03 & 2,16 & 2,5 & 24 & 3,3 & 14,78 & 27,8 & 330 & 54 & 41 & 30 \\
\hline $\begin{array}{l}\text { C1 } \\
(9 / 2015)\end{array}$ & 8,03 & 1,4 & 2,8 & 25 & 3,6 & 14,8 & 8 & 110 & 62 & 33 & 45 \\
\hline $\begin{array}{l}\text { C2 } \\
(9 / 2015)\end{array}$ & 8,21 & 1,2 & 3,5 & 29 & 1,7 & 15,9 & 18 & 340 & 61 & 35 & 25 \\
\hline $\begin{array}{l}\text { C3 } \\
(9 / 2015)\end{array}$ & 8,4 & 0,8 & 3,6 & 20 & 5 & 15 & 19 & 300 & 59 & 36 & 25 \\
\hline $\begin{array}{l}\text { C4 } \\
(9 / 2015)\end{array}$ & 8,5 & 1,8 & 2,8 & 30 & 1,3 & 18 & 6 & 280 & 58 & 39 & 19 \\
\hline C5 & 8,67 & 2,9 & 3,2 & 19 & 5,4 & 14 & 35 & 250 & 56 & 40 & 15 \\
\hline
\end{tabular}


International Journal of Agriculture, Environment and Bioresearch

Vol. 5, No. 01;2020

ISSN: 2456-8643

\begin{tabular}{|l|l|l|l|l|l|l|l|l|l|l|l|}
$(9 / 2015)$ & & & & & & & & & & \\
\hline MOY & 8,362 & 1,62 & 3,18 & 24,6 & 3,4 & 15,54 & 17,2 & 256 & 59,2 & 36,6 & 25,8 \\
\hline $\begin{array}{l}\text { C1 } \\
(7 / 2016)\end{array}$ & 7,5 & 1,8 & 2,6 & 25 & 3,5 & 15,3 & 17 & 266 & 54 & 45 & 55 \\
\hline $\begin{array}{l}\text { C2 } \\
(7 / 2016)\end{array}$ & 7,95 & 1,3 & 2,9 & 28 & 1,9 & 16 & 32 & 430 & 55 & 40 & 40 \\
\hline $\begin{array}{l}\text { C3 } \\
(7 / 2016)\end{array}$ & 8,02 & 1,5 & 2,4 & 21 & 5 & 13 & 29 & 310 & 56 & 42 & 20 \\
\hline $\begin{array}{l}\text { C4 } \\
(7 / 2016)\end{array}$ & 8,05 & 3,4 & 2,8 & 31 & 1,5 & 18 & 20 & 310 & 57 & 38 & 20 \\
\hline $\begin{array}{l}\text { C5 } \\
(7 / 2016)\end{array}$ & 8,15 & 3,7 & 2,6 & 18 & 5,3 & 14 & 47 & 300 & 51 & 41 & 19 \\
\hline MOY & 7,934 & 2,34 & 2,66 & 24,6 & 3,44 & 15,26 & 29 & 323,2 & 54,6 & 41,2 & 30,8 \\
\hline $\begin{array}{l}\text { C1 } \\
(7 / 2017)\end{array}$ & 8,5 & 1,6 & 2,9 & 24 & 3,9 & 14,8 & 9 & 110 & 63 & 30 & 41 \\
\hline $\begin{array}{l}\text { C2 } \\
(7 / 2017)\end{array}$ & 7,3 & 1,3 & 3,7 & 29 & 1,8 & 15,6 & 19 & 320 & 62 & 34 & 40 \\
\hline $\begin{array}{l}\text { C3 } \\
(7 / 2017)\end{array}$ & 8,03 & 0,9 & 3,8 & 20 & 6 & 13 & 19,5 & 290 & 59 & 37 & 20 \\
\hline $\begin{array}{l}\text { C4 } \\
(7 / 2017)\end{array}$ & 8,21 & 1,9 & 2,9 & 30 & 1,7 & 17 & 7 & 270 & 57 & 36 & 19 \\
\hline $\begin{array}{l}\text { C5 } \\
(7 / 2017)\end{array}$ & 8,6 & 2,9 & 3,6 & 19 & 5,6 & 14,5 & 36 & 245 & 58 & 39 & 17 \\
\hline MOY & 8,128 & 1,72 & 3,38 & 24,4 & 3,8 & 14,98 & 18,1 & 247 & 59,8 & 35,2 & 27,4 \\
\hline
\end{tabular}

Texture

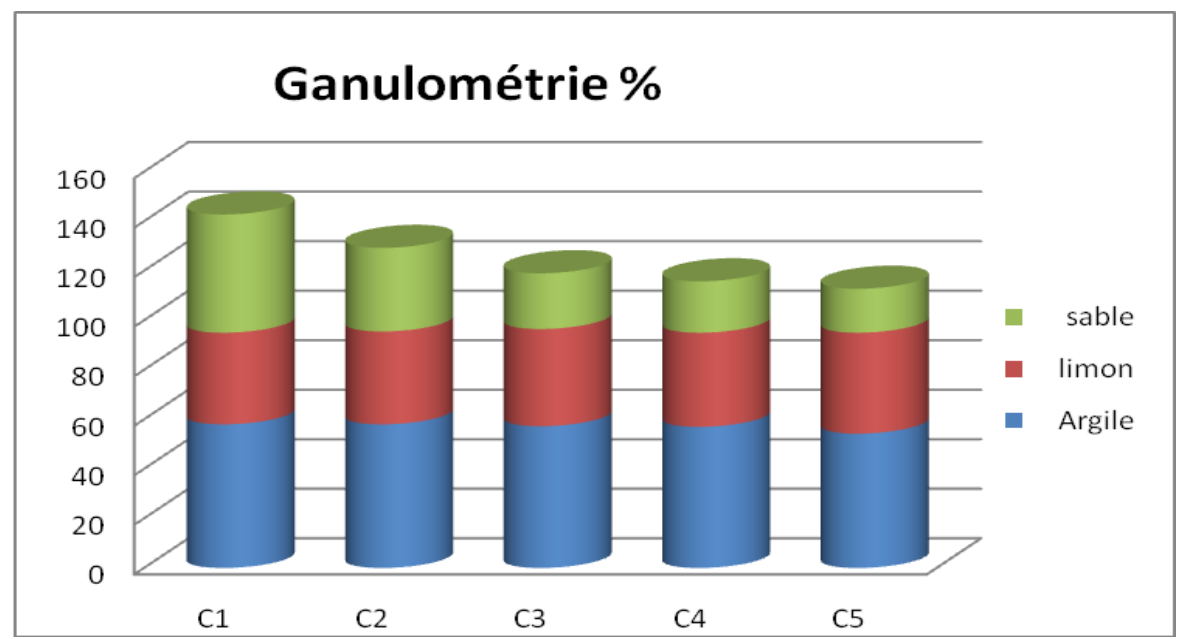

Figure 1: granulometric characterization of horizon soils $(0-20 \mathrm{~cm})$ of rice paddies studied.

The texture of the soils is clay with the exception of Clos $\mathrm{C} 1$ which displays a balanced texture. 


\section{The pH}

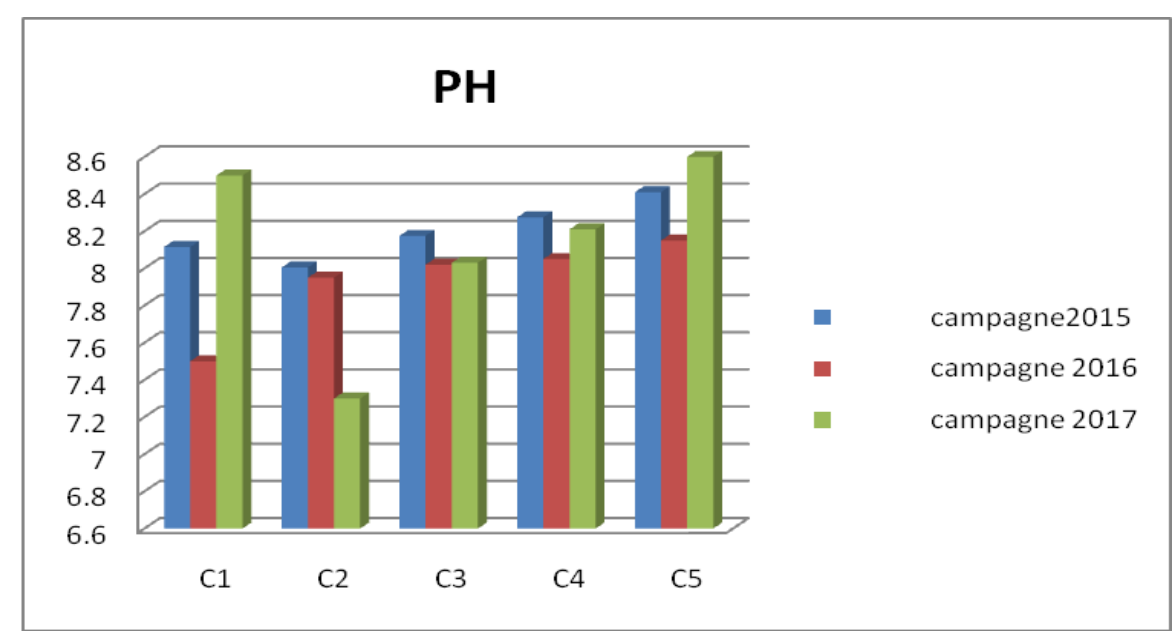

Figure2: $\mathrm{pH}$ of the soils of the rice fields studied

Soil $\mathrm{pH}$ is a synthetic expression of the physicochemical conditions that partly who are preside soil structure, microbial activity, and the availability of nutrients elements [9].

The $\mathrm{pH}$ is an important parameter of the soil dynamics, it is a key in agronomy because their degree of acidity or basicity plays a very important role on the assimilation of nutrients by the plant, it has an influence on three important components of soil fertility: nutrient bioavailability, biological activity and structural stability, $\mathrm{pH}$ variation is dependent on seasonal variations and soil buffering capacity (the number of ions in reserve on the complex clay-humic), the soil water status, its temperature and the presence or absence of a culture an active growth period [1,6]. The results of the $\mathrm{pH}$ analysis are presented in the table, showing that the majority of soils studied from Gharb, have $\mathrm{pH}$. They range from 8.67 and 7.3 with an average of 7.98. $\mathrm{pH}$ values appear to be in agreement with the level of alkalinity encountered in soils.

\section{Organic matter}

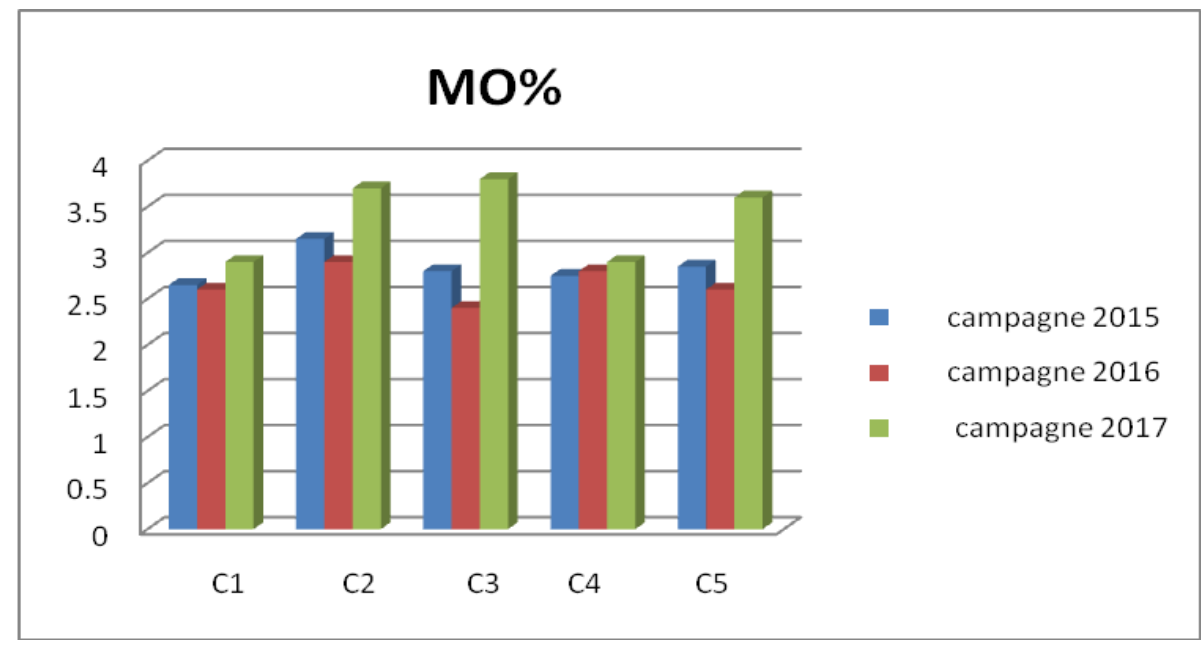

Figure3: Organic matter in the soils of the rice fields studied. 
The results of the $\mathrm{pH}$ analysis are presented in the table, showing that the majority of soils studied from Gharb, have $\mathrm{pH}$. They range from 8.67 and 7.3 with an average of 7.98. $\mathrm{PH}$ values appear to be in agreement with the level of alkalinity encountered in soils.

The results of the soils studied vary from 3.80 and 2 . With average 2.9 which show that soils analyzed are poor in organic matter and it that can be explained by the influence of the arid and semi-arid climate of our region study.

\section{Phosphorus assimilable}

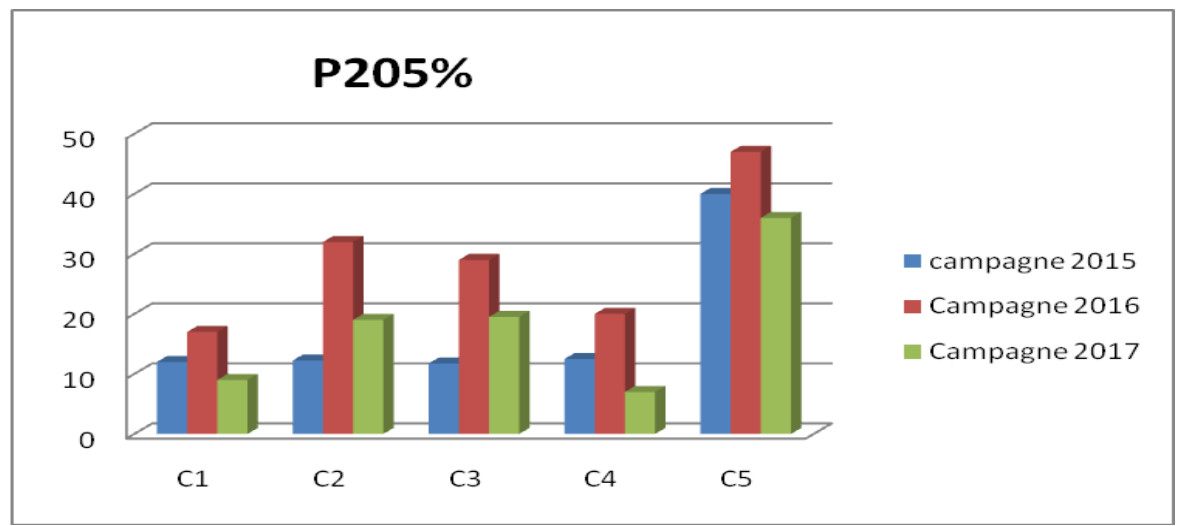

Figure 4: Phosphorus content assimilable of soils paddies studied

Phosphorus is one of the major elements indispensable for the growth and development of vegatable. In he plays particular, it plays essential a key role in setting up the root system, photosynthesis and vegatable reproduction. Their variation depends on the physicochemical properties of the soil [8].

The results of soil samples studied range from 45 to 6 with average $25.5 \mathrm{ppm}$ are characterize by low concentration phosphorus $\mathrm{P} 2 \mathrm{O} 5$. Which requires a reasonable phosphate fertilization.

\section{Exchangeable potassium}

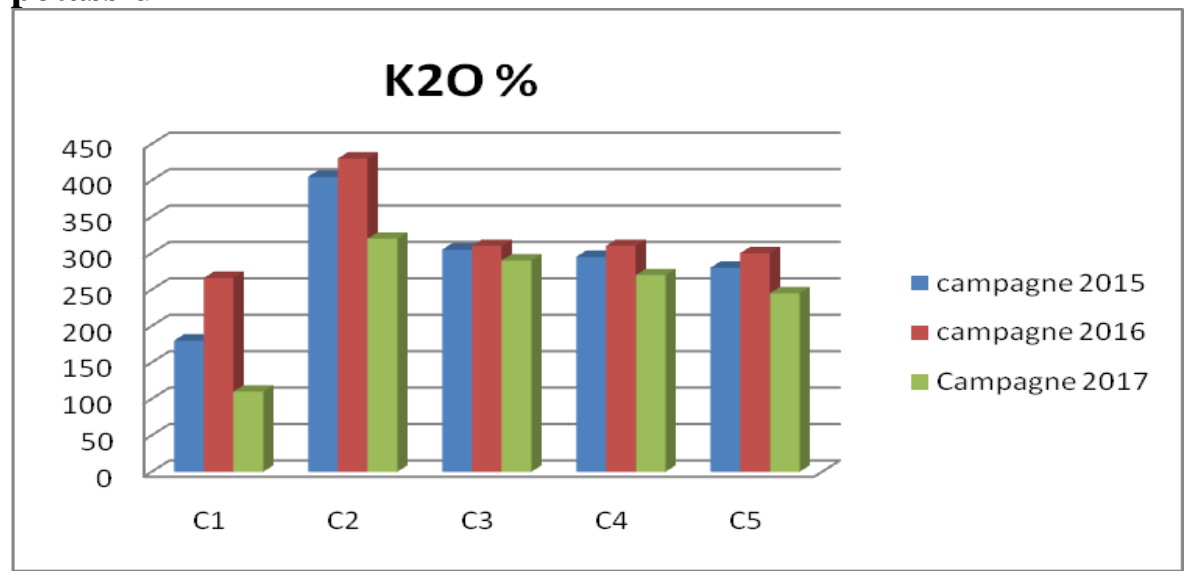

Figure 5: Exchangeable potassium content of the rice paddy soils studied. 
Potassium is absorbed by the plant in its ionic form $\mathrm{K}+$. It is essential for the translocation of sugars and for the formation of starch. It is interved in osmotic and ionic regulation, as well as in the opening and closing process of stomata. Potassium is necessary for several enzyme functions and for the metabolism of proteins and carbohydrates. Their variation depends on the physicochemical properties of the soil [8].

The average value of the sampled sites reaches $290 \mathrm{ppm} \mathrm{K2O}$, indicating that these soils are rich in potassium. The excess of potassium can converted into salt and thus pollute the groundwater by percolation and infiltration which can also cause magnesium deficiencies for crops [10].

\section{Limestone:}

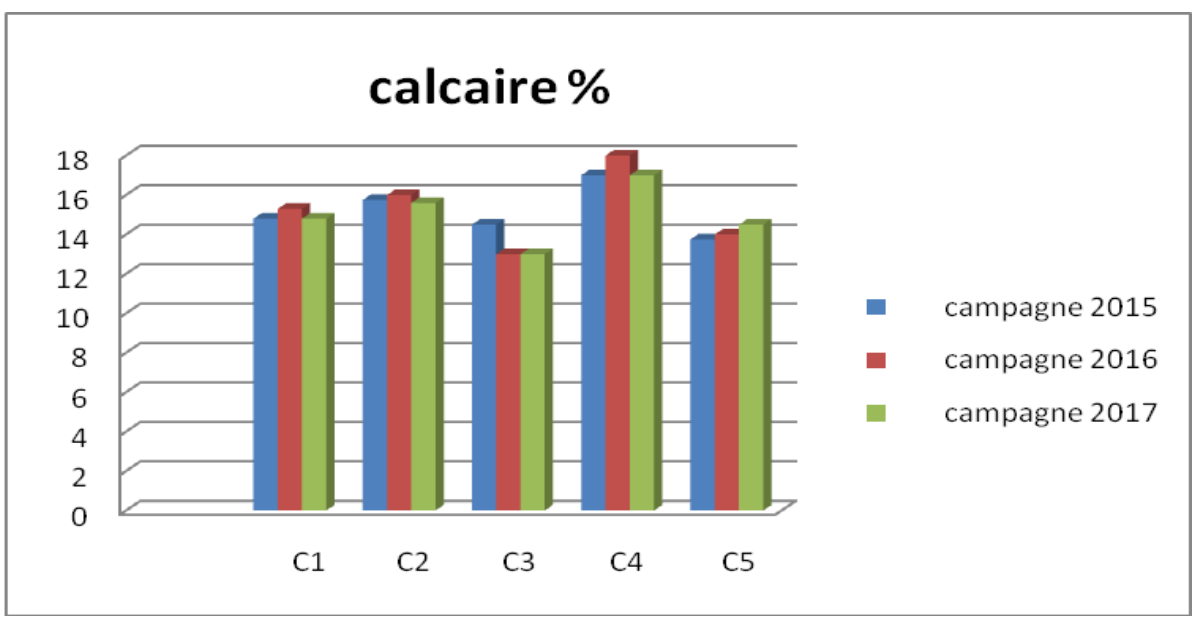

Figure 6: Limestone content of the rice paddy soils studied.

The percentage in limestone of the superficial horizon varies from 13 to $15.9 \%$ with an average of $14.45 \%$.

\section{Exchangeable sodium}

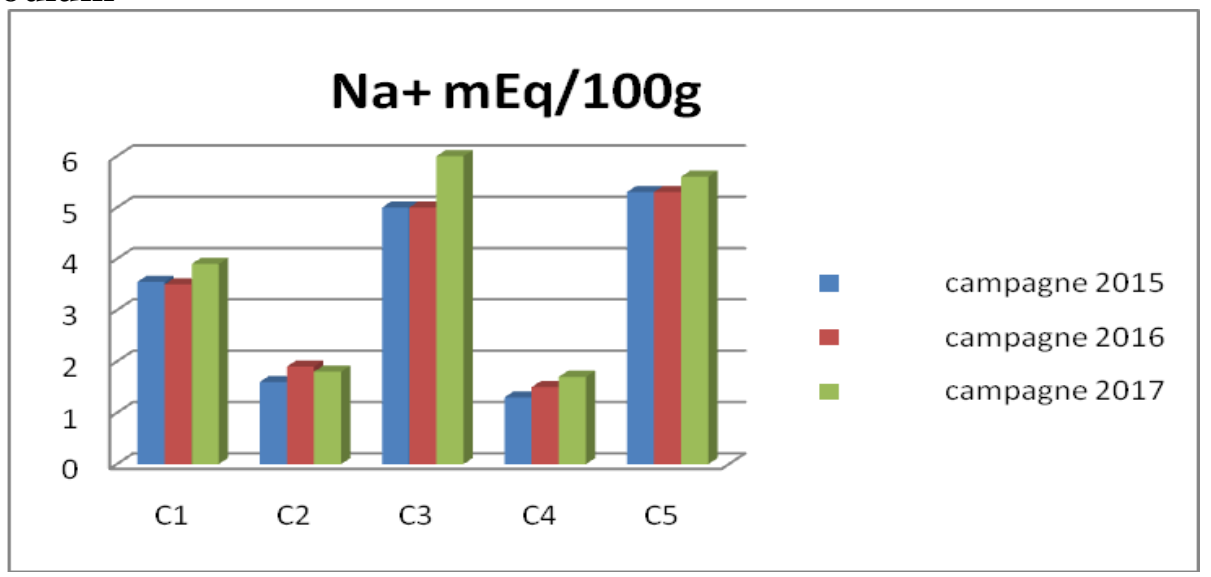

Figure7: Exchangeable $\mathrm{Na}+$ content of the rice paddy soils studied.

The sodium contents of the surface layer vary widely from (1.3 to $6 \mathrm{Meq} / 100 \mathrm{~g})$ with an average of 3.65 Méq / $100 \mathrm{~g}$. High sodium of concentrations are toxic to rice [4]. The sodium 
soils require a chemical amendment, for example with gypsum, which confer the soil a calcium sulphate content sufficient to flocculate the clay: the sodium is progressively from the adsorbent complex by the calcium and is entrained beyond the root zone by leaching [2].

\section{The cation exchange capacity}

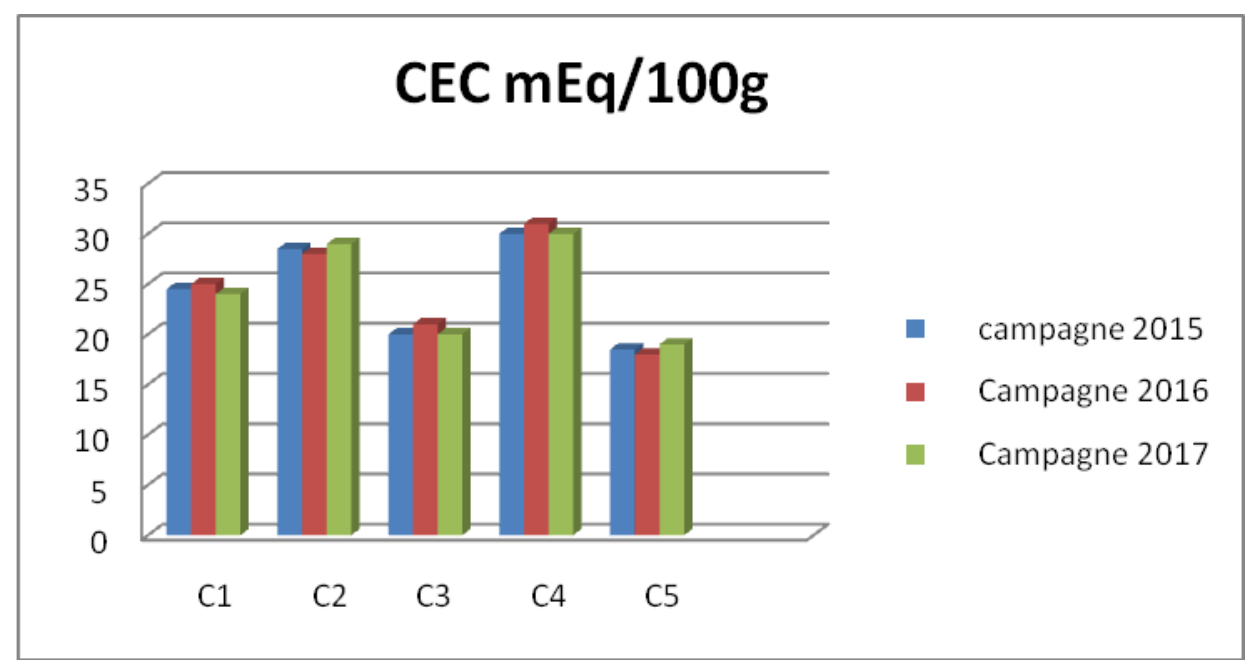

Figure 8: cation exchange capacity of the soils of the rice fields studied.

The strong cation exchange capacity is to report at the rate of clay on the surface. Sedimentation favors the predominance, in the clay fraction, of smectics characteristic of oceanic inputs [5].

\section{Electrical conductivity}

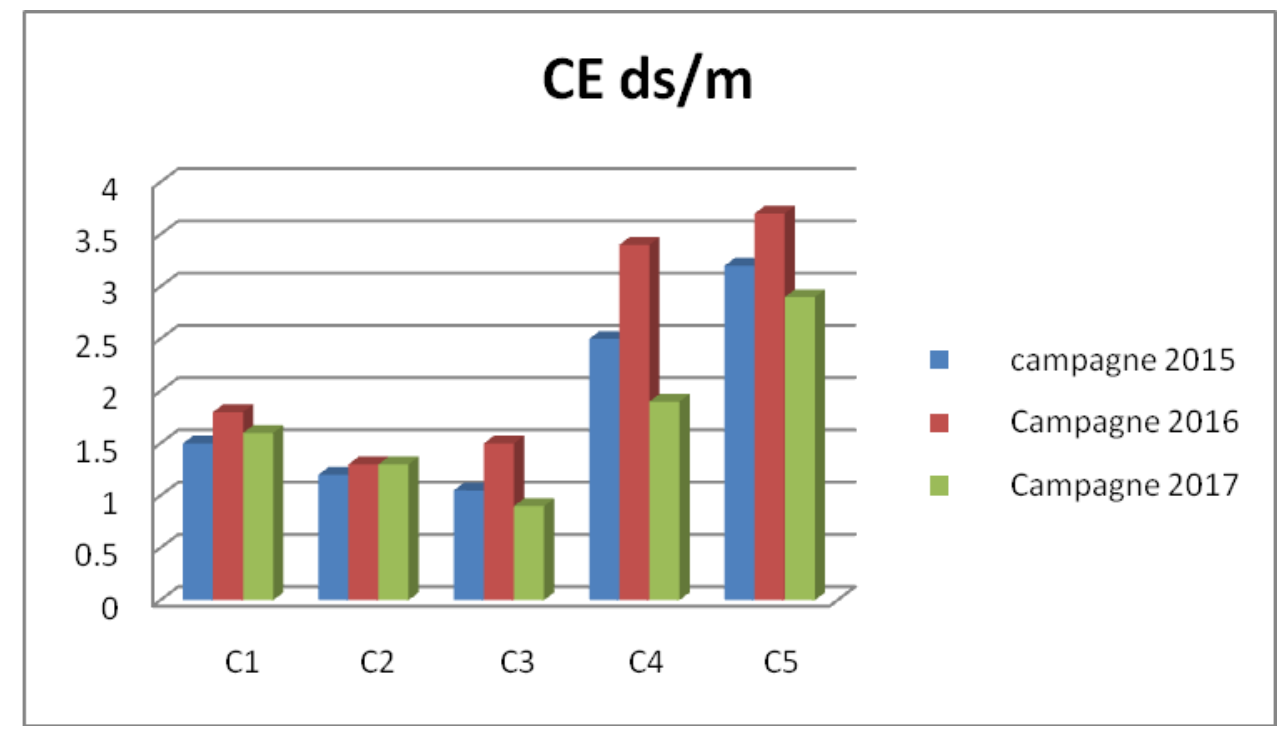

Figure 9: electrical conductivity of the soils of the rice fields studied. 
Vol. 5, No. 01; 2020

ISSN: $2456-8643$

All the clos studied have electrical conductivity (CE) show that values less than $4 \mathrm{ds} / \mathrm{m}$. According to the standards established by Richards in 1954, these plots are classified in the category of unsalted soils. The electrical conductivity decreases 1.5 to 1.05 to 0.9 between 2015, 2016 and 2017.

\section{Statistical data processing:}

Examination of the numerical results of this ACP shows that the eigenvalues indicate that the F1 axis explains nearly half (is $41.57 \%$ ) of the total variance of the data. The F2 axis indicates $22.06 \%$ of the total variability of the data. Thus, $63.62 \%$ of the variability in the data table is extracted by the factorial plane F1 X F2. From this fact, the analysis of the results of the ACP will be done made by limiting themselves to these first two axes.

The correlation circle shows that eleven variables taken into account in the ACP contribute to the definition of the factorial plane F1 * F2 are presented in Figure 4.

The F1 axis explains $36.44 \%$ of the total variance and makes it possible to discriminate Clay, organic matter, sand, CEC and negative Limestone with salts rich in $\mathrm{pH}$, sodium, P2O5, conductivity, silt and $\mathrm{K} 2 \mathrm{O}$ high in the positive abscissae, reflecting a good soil quality.

The F2 axis explains $17.39 \%$ of the total variance and makes it possible to contrast the alkaline soils in the positive ordinates with the rich Clay and organic matter and $\mathrm{pH}$ and sodium in the negative ordinates

Table 2: the eigenvalue and the percentage of variance of the first eight axes of the ACP

\begin{tabular}{|l|r|r|r|r|r|r|r|r|}
\hline & F1 & F2 & F3 & F4 & F5 & F6 & F7 & F8 \\
\hline Valeur propre & 3,326 & 1,765 & 1,312 & 0,933 & 0,502 & 0,102 & 0,050 & 0,009 \\
\hline $\begin{array}{l}\text { Variabilité } \\
(\%)\end{array}$ & 41,573 & 22,063 & 16,403 & 11,659 & 6,280 & 1,278 & 0,625 & 0,118 \\
\hline \% cumulé & 41,573 & 63,637 & 80,040 & 91,699 & 97,979 & 99,258 & 99,882 & 100,000 \\
\hline
\end{tabular}


Vol. 5, No. 01; 2020

ISSN: 2456-8643

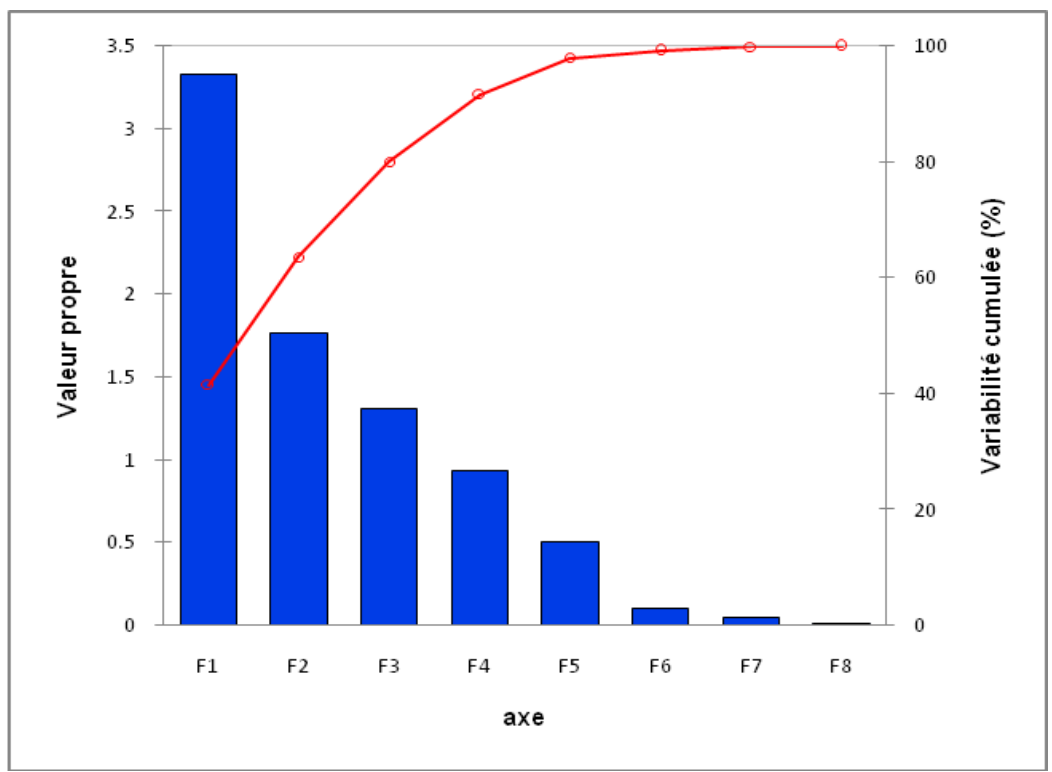

Figure 10: Graphical representation of eigenvalues

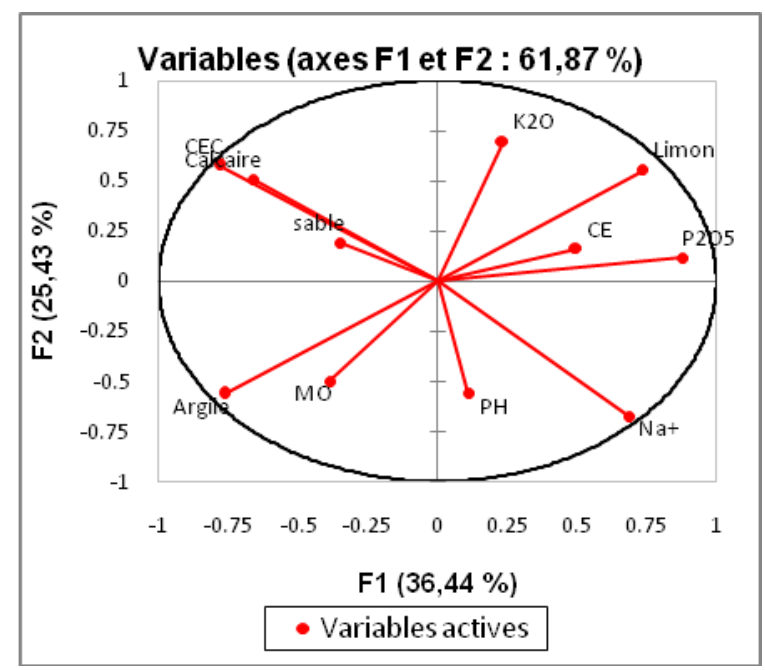

\section{DISCUSSION AND CONCLUSION}

The characterization of the physico-chemical parameters of the clos the soils of the paddy fields of the study area, $\mathrm{pH}$ neighbour 7.98, at the beginning of the moderately basic cycle, fairly high organic matter, limestone soils with high cation exchange capacity.

Soil $\mathrm{pH}$ is a synthetic expression of the physicochemical conditions who presides in part govern soil structure, microbial activity and the availability of nutrients. [9]. 


\section{International Journal of Agriculture, Environment and Bioresearch}

Vol. 5, No. 01;2020

ISSN: $2456-8643$

The $\mathrm{pH}$ is an important parameter of the soil dynamics, it is a key in agronomy because their degree of acidity or basicity plays a very important role on the assimilation of elements nutrients by the plant, it has an influence on three important components of soil fertility: the bioavailability of nutrients, biological activity and structural stability, The variation in $\mathrm{pH}$ depends on seasonal variations and soil buffering power (the number of ions in reserve on the complex clay-humus), the hydric state of the soil, its temperature and the presence or absence of a crop during an active growth period $[\mathbf{1 , 6}]$.

Soil organic matter is an important indicator of the degradation of soil quality due to its contribution to soil stability, increasing the soil's water retention capacity, fixation of mineral elements, and the substrate for soil microorganisms. The organic matter content soils is overall influence by climatic factors, vegetation, soil texture, topographic conditions, influencing the microclimate and drainage and cultural practices [7].

In fact, organic matter protects against the aggregates from bursting at the time of humiliation. In the Chélif plain in Algeria, [16] also found a significant and positive correlation between structural stability and the rate of organic matter.

The high sodium concentrations are toxic for Rice [4].

Sodium soils require a chemical amendment, for example with gypsum, which gives the soil a calcium sulphate content sufficient to flocculate the clay: sodium is gradually removed from the complex of adsorbent by calcium and is entrained beyond the root zone by leaching [2].

The samples analyzed are limestone-limestone.

The strong cation exchange capacity is related to the surface clay content. Sedimentation favors the predominance, in the clay fraction, of smectics characteristic of oceanic inputs [5]. In areas near the Atlantic coast or still in those with sedimentation in progress or very recent at and benefit marine than fluvial, smetite-type clays are locally majority compared to kaolinites [11].

All the clos studied have electrical conductivity (CE) showing that values less than $4 \mathrm{ds} / \mathrm{m}$. According to the standards established by Richards in 1954, these plots are classified in the category of unsalted soils.

The flooded soils of the en clos appear to be well provided in elements nutrients, probably in bond connection with the application of chemical fertilizers, these elements are depleted during the plant cycle.

Phosphorus is one of the major elements indispensable for the growth and development of vegetable. It plays in particular an essential role in the establishment of the root system, photosynthesis and reproduction of the vegetal. Their variation depends on the physico-chemical properties of the soil [8].

Potassium is absorbed by the plant in its $\mathrm{K}+$ ionic form. It is essential for the translocation of sugars and for the formation of starch. It is involved in osmotic and ionic regulation, as well as in the process of opening and closing stomata. Potassium is necessary for several enzymatic 
Vol. 5, No. 01; 2020

ISSN: $2456-8643$

functions and for the metabolism of proteins and carbohydrates. Their variation depends on the physico-chemical properties of the soil [8].

Maintaining a balance of nutrients elements in rice fields required the use of exclusively mineral fertilizers.

To supplement the supply of nitrogen fertilizers, it will be able to return residues from the rice harvest, to promote the growth of cyanobacteria which fix atmospheric nitrogen, aquatic ferns like the genus Azolla, in symbiotic association with cyanobacteria.

\section{REFERENCE}

1. Baize D., Guide des analyses en pédologie: choix, expression, présentation, interprétation 2e éd, INRA-paris 255 (2000).

2. Bower C.A., Reitemeier R.F. et Fireman, M., (1952): Exchangeable cation analysis of saline and alkali soils. Soil Sci, $\mathrm{n}^{\circ} 73$ : pp. 251-261

3. COMBE, M. 1969. Cartes hydrogéologiques de la plaine du Rharb au 1/100000. Notes et mémoires du service géologique du Maroc.

4. Dakak H., Soudi B., Ben Mohammadi A., Douaik A., Badraoui M., Moussadek R., (2011) : Prospection de la salinité des sols par induction électromagnétique sur la plaine du Tadla (Maroc) : tentative d'optimisation par analyse géostatistique. Sécheresse, vol. $22, \mathrm{n}^{\circ} 83, \mathrm{p}: 178-185$.

5. Delaunois A., Ferrie Y., Bouche M., Colin .C et Rionde C., Guide pour la description et l'évaluation de la fertilité des sols (2008).

6. Dinon E., Gerstmans, L'Influence du pH sur l'assimilation des éléments nutritifs du sol par les plantes et sur la variété des plantes, Université de Liège, (2008).

7. Drouet Th. Pédologie BING-F-302,137 (2010).

8. Elalaoui.A, Fertilisation Minérale des Cultures Les éléments fertilisants majeurs (Azote, Potassium, Phosphore), Bulletin mensuel d'information et de liaison du PNTA (2007).

9. Genot V., Colinet G. \& Bock L., 2007. La fertilité des sols agricoles et forestiers en région wallonne. Rapport analytique 2006 sur l'État de l'Environnement Wallon. Gembloux, Belgique : Laboratoire de Géopédologie, Unité Sol-Écologie-Territoire, Faculté universitaire des Sciences agronomiques.

10. Koné M., Bonou L., Bouvet Y., Joly P.; Koulidiaty J., Etude de la pollution des eaux par les intrants agricoles : cas de cinq zones d'agriculture intensive du Burkina Faso 2IE, 
Institut International d'Ingénierie de l'Eau et de l'Environnement SST - Numéro 17 (2009).

11. Marius (C.) - Mangroves du Sénégal et de la Gambie : écologie, pédologie, géochimie : mise en valeur et aménagement. - Trav. Doc. ORSTOM, 1985, (183), 25-56.

12. MICHARD, A. 1976. Eléments de géologie Marocaine: Notes et Mémoires du Service Géologique, v. 252. Rabat: Editions du Service Geologique du Maroc.

13. Olsen S.R. et al., (1954): Estimation of available phosphorous in soils by extraction with sodium bicarbonate. Cir. U.S. Dep. Agr., n 939, p: 1-19.

14. ROCH E., 1950 .Histoire stratigraphique de la plaine du Gharb au 1/100000 .Notes et Mém.Ser.Géo.Maroc, 221 bis ,39p.

15. Rokhaya S.D., 1998. Riziculture et dégradation des sols en vallée du fleuve Sénégal : analyse comparée des fonctionnements hydro-salins des sols du delta et de la moyenne vallée en simple et double riziculture. Thèse de doctorat, Univ .Cheikh Anta Diop .Faculté des sci.et Tech. Dakar, 176p.

16. Saidi D., Douaoui A ., Le Bissonnais Y. and Walter C. (1999) Sensibilité de la surface des sols des plaines du Chélif à la dégradation structurale". Étude et Gestion des Sols., 6(1): 15-25.

17. U.S.S.L.S. (United State Salinity Laboratory Staff): Diagnosis and improvement of saline and alkali soils.US Department of Agriculture, Handbook n60, U. S. Gov. Print. Office, Washington DC, (1954).

18. Van Rast, E., Verloo, M., Demeyer, A., Pauwels, J.M., 1999. Manual for the Soil Chemistry and Fertility Laboratory. Ed, 1999.

19. Walkley A. et Black C. A., (1934): An examination of the Degtjareff method for determining soil organic matter and a proposal modification of the chromic acid titration method. Soil Science, Vol. 37, p. 29-38 